\title{
TESTIMONIAL PRIVILEGES AND CONFLICT OF LAWS
}

\author{
WILLIS L. M. ReESE* \\ BARRY D. LEIWANT $\dagger$
}

\section{INTRODUCTION}

In many respects, testimonial privileges in conflict of laws provide an ideal topic for discussion. The major privileges are not great in number. The same can be said of the policies that are responsible for the acceptance or rejection of these privileges although the particular local rules relating to them differ quite widely in detail from state to state. Also, at least in the usual case, only a relatively few states will have an interest in the decision of an issue of privilege. In short, testimonial privileges come as close as may be possible to providing laboratory conditions for the construction of choice-of-law rules or a choice-of-law approach. ${ }^{1}$ To be sure, the relevant cases are relatively sparse and not particularly helpful in their reasoning. But this fact adds to the zest of the task and, quite possibly, to the feasibility of setting forth the directions in which it is believed the courts should go. We believe that our general approach has validity for the field of choice of law in general. We hope that our contribution will mark a step, albeit a small one, along the path that David Cavers has so brilliantly charted.

The privileges with which we will deal are those concerned with confidential communications. Prominent among those excluded from our study is the privilege against self-incrimination, which is honored in all states and whose

\footnotetext{
* Charles Evans Hughes Professor of Law and Director of the Parker School of Foreign and Comparative Law, Columbia University; Reporter, Restatement (Second) of Conflict of Laus.

$\dagger$ Associate Appellate Counsel, Criminal Appeals Bureau, Legal Aid Society of New York; formerly Associate in Law, Columbia University.

1. This may account for the attention the subject has received from a number of eminent scholars. See, e.g., Berger, Privileges, Presumptions and Competency of Witnesses in the Federal Court: A Federal Choice-of-Law Rule, 42 Brooklyy L. REv. 417 (1976); Sedler, The Erie Outcome Test as a Guide to Substance and Procedure in the Conflict of Laws, 37 N.Y.U. L. REv. 813 (1963); Weinstein, Recognition in the United States of the Privileges of Another Jurisdiction, 56 Colum. L. Rev. 535 (1956), The most recent study is Sterk, Testimonial Privileges: An Analysis of Horizontal Choice of Law Problems, 61 Minn. L. REv. 461 (1977), which has stimulated our thinking immeasurably. This article came to our attention after we were well advanced in our work. We decided to press on in the hope that we could make an additional contribution.

On rare occasions, choice-of-law problems involving privileges may be regulated by treaty. See, e.g., Article 11 of the Hague Convention of March 18, 1970 on the Taking of Evidence Abroad in Civil or Commercial Matters, 23 U.S.T. 2555, T.1.A.S. No. 7444; 16 Am. J. Comp. L. 594 (196869) (draft). This Convention has been ratified by the United States.
} 
application is mandated by the United States Constitution. ${ }^{2}$ Of the privileges that concern us, the ones that are of most ancient vintage and probably the most widely recognized are those that involve oral or written interchanges between client and lawyer, doctor and patient, priest and penitent, and husband and wife. All states recognize to a greater or lesser extent the attorney-client and husband-wife ${ }^{3}$ privileges, while a considerable majority do the same for those of doctor-patient and priest-penitent. A more recent development has been the recognition by a substantial number of states, again with differences in detail, of a reporter's privilege ${ }^{4}$ and of a privilege for psychiatrists and psychologists. ${ }^{5}$ Other privileges, including one for accoun-

2. See Malloy v. Hogan, 378 U.S. 1 (1964).

Other privileges we have excluded from consideration are those which concern trade secrets, see generally $8 \mathrm{~J}$. Wicmore, EvideNCE $\$ 2212$ (J. MCNaughton rev. 1961); political votes, see generally 8 Wigmore, supra, $\$ 2214$; Nutting, Freedom of Silence: Constitutional Protection Against Governmental Intrusions in Political Affairs, 47 МrCH. L. REv. 181 (1948); judges and jurors, see generally 8 Wigmore, supra, $\S \S 2345-64$; and official information in the possession of the government, see generally 8 WIGMORE, supra, $\$$ 2367-79; Note, Discovery of Government Documents and the Official Information Privilege, 76 Colum. L. Rev. 142 (1976); Note, The Required Report Privileges, 56 Nw. U.L. REv. 283 (1961).

3. There are actually two privileges that involve the marital relationship. Recognized in all states is the privilege which protects from disclosure confidential communications between husband and wife. See, e.g., N.J. STAT. ANN. 2A:84A-22 (1976). In addition some jurisdictions continue to recognize the common law rule that shielded one spouse from adverse testimony by the other. See, e.g., WYo. STat. § 1-142 (Supp. 1975). However this prohibition has been entirely abolished in a number of states and severely eroded in others, especially as it affects testimony in civil cases. See generally 8 Wigmore, supra note 2 , $\S 2227-45,2332-41$; C. McCormick, Evidence $\S \S 66,78-86$ (2d ed. E. Cleary, et al. 1972).

4. The reporter's privilege varies widely with respect to the communications protected, and when they are protected. See generally Note, Search and Seizure of the Media: A Statuton, Fourth Amendmemt and First Amendment Analysis, 28 STAN. L. REv. 957, 960-71 (1976); Comment, Neusmen's Privilege Tuo Years After Branzburg $\%$. Haves: The First Amendment in Jeopardy, 49 Tul. L. Rev. $417,429-36$ (1975). In truth, all of the privileges that protect confidential communications vary to some degree from state to state. For example, if a conversation between an attorney and his client is overheard unexpectedly by a third person, some states do not permit the client to assert the privilege and prevent the eavesdropper from testifying. See, e.g., Schwartz v. Wenger, 267 Minn. 40, 124 N.W.2d 489 (1963). But most states do extend the attorney-client privilege to this situation. See, e.g., N.J. STAT. ANN. 2A:84A-20 (1976). In some states the doctor-patient privilege is deemed waived whenever the patient puts his physical condition in issue, while other jurisdictions do not consider such action sufficient to constitute a waiver. Compare Koump $v$. Smith, 25 N.Y.2d 287, 250 N.E.2d 857, 303 N.Y.S.2d 858, 864 (1969) with State ex rel. Lambdin v. Brenton, 21 Ohio St. 2d, 254 N.E.2d 681 (1970). The priest-penitent privilege applies in some states only to confessions required by church doctrine, primarily those made to Roman Catholic priests. See, e.g., Mo. AnN. STat. \$ 491.060(4) (Vernon 1952). The modern trend has been to expand the scope of the privilege to include all confidential communications made to a clergyman in his professional capacity as a spiritual adviser. See, e.g., N.Y. Crv. Prac. Law $\$ 4505$ (McKinney Supp. 1976); Kruglikov v. Kruglikov, 29 Misc. 2d 17, 217 N.Y.S.2d 845 (Sup. Ct. 1961), appeal dismissed, 16 App. Div. 2d 735, 226 N.Y.S.2d 931 (1962).

5. In states that have a doctor-patient privilege, communications to psychiatrists are protected because psychiatrists are physicians who specialize in treating emotional disorders. See, e.g., HAw. Rev. Stat. \$621-20.5 (Supp. 1975). A few states, most of which do not recognize the doctorpatient privilege, have enacted a separate privilege for psychiatrists, see, e.g., TEnn. Code Ann. $\S 24-112$ (Supp. 1976), while many states have enacted a privilege to protect communications 
tants, ${ }^{6}$ have been recognized by a smaller number of states. ${ }^{7}$

The policies responsible for these privileges have been discussed at length by able scholars. We do not propose to present such detailed discussion here. Suffice it to say that the underlying policies are rarely described explicitly in either legislative materials or judicial decisions. As a result, any statement concerning the policies underlying a particular rule of privilege must rest in large part on surmise. Undoubtedly, one policy, and probably the most important policy, responsible for all of these privileges is the encouragement of what are thought to be desirable confidences. ${ }^{8}$ To be sure, one can argue in this skeptical age that, whether privileged or not, spouses would speak freely with one another, patients would confide in their doctors, and penitents would confess to their priests. There is, however, no way of being sure that this is the case. ${ }^{9}$ In any event, it seems probable that the policy of encouraging confidences was largely responsible for the creation of these privileges and is also responsible for their continued vitality. ${ }^{10}$ There can be no question, in any event,

between psychologists and their patients. See, e.g., Wash. Rev. Code $\$ 18.83 .110$ (1976). An alternative approach is to recognize a comprehensive psychotherapist-patient privilege to cover all forms of counseling. See, e.g., Cal. Evid. Code $\$$ 1010-1028 (West 1966 \& Supp. 1977).

6. See, e.g., Ill. Ann. STAt. ch. 1101/2, 51 (Smith-Hurd 1977).

7. Other minor privileges include those which shield from disclosure communications between social worker and client, see, e.g., N.Y. Crv. Prac. Law $\$ 4508$ (McKinney Supp. 1976); Comment, Underprivileged Communications: Extension of the Psychotherapist-Patient Pritilege to Patients of Psychiatric Social Workers, 61 CAL. L. REv. 1050 (1973); between school counselor and student, see, e.g., S.D. Compiled Laws Ann. $\S \S 19-2-5.1$ to 5.2 (Supp. 1977); Note, Testimonial Privileges and the Student-Counselor Relationship in Secondary Schools, 56 Iowa L. Rev. 1323 (1971); and between marriage counselors and their clients. See, e.g., Мıсн. Сomp. Laws Ann. \$338.1043 (1976); Note, Privileged Communications: A Case By Case Approach, 23 ME. L. Rev. 443, 450 (1971).

8. The significance of the policy of encouraging communications as a motive for the recognition of testimonial privileges is illustrated by the introductory statement to the Colorado privilege statute: "There are particular relations in which it is the policy of the law to encourage confidence and to preserve it inviolate; therefore, a person shall not be examined as a witness in the following cases: . . . ." Colo. REv. STAT. § 13-90-107(1) (1974 \& Supp. 1976). Other states' codifications contain similar expressions of policy. See, e.g., Mont. Rev. Codes AnN. \$ 93-701-4 (1964 \& Supp. 1976).

9. For a discussion of one inconclusive attempt to determine the extent to which people are aware of and rely on testimonial privileges, see generally Note, Functional Overlap Between the Lauyer and Other Professionals: Its Implications for the Privileged Communications Doctrine, 71 Yale. L. REv. 1226 (1962).

10. At early common law the attorney-client privilege apparently rested on the notion that a lawyer should not be forced to violate his obligation as a gentleman to keep secret a matter told to him in confidence. See 8 WIGMORE, supra note $2, \S \S 2286,2290$. However by the eighteenth century, the courts had articulated the view that it is essential to the effective function of the attorney-client relationship that the client be encouraged to communicate freely to his lawyer without any fear that his secrets will be disclosed. This purpose has been reaffirmed ever since by countless courts and commentators. See, e.g., United States v. Louisville \& Nashville R.R., 236 U.S. 318,336 (1915); Baird v. Koerner, 279 F.2d 623, 629-30 (9th Cir. 1960); Lee Nat'l Corp. v. Deramus, 313 F. Supp. 224, 226 (D. Del. 1970); In re Lanza, 6 Misc. 2d 411, 163 N.Y.S.2d 576, 580, 583 (Sup. Ct.), aff'd, 4 App. Div. 2d 252, 164 N.Y.S.2d 534 (1957); McCormick, supra note 3 , $\$ 87$; Model Code of Evidence rule 210, comment (a) (1942); Sedler and Simeone, The Realities of Attorney-Client Confidences, 24 Oнго ST. L.J. 1, 1-10 (1963); Note, The Attorney-Client Prizilege and the Corporation in Shareholder Litigation, 50 S. CAL. L. REv. 303, 304-08 (1977); Note, 
that this policy is responsible for the recent, widespread recognition of the reporter's privilege. ${ }^{11}$

The protection of privacy is another policy which may have played a role in the creation of some of these privileges and may be responsible, at least in part, for their continued existence. This policy rests on the notion that certain relationships should be shielded, at least to some degree, from public scrutiny and from interference by the state. ${ }^{12}$ The privileges which protect communications between psychotherapist and patient and between husband and wife are the ones most likely to have been affected by this policy. ${ }^{13}$ But it may also

Attorney-Client Privilege for Corporate Clients: The Control Group Test, 84 Harv. L. Rev. 424, 424-25 (1970).

The policy of encouraging confidences is also at the heart of the privilege which protects confidential communication between husband and wife. This privilege is designed to foster happy marriages by encouraging trust and candor in the marital relationship. See, e.g., State v. Thorne, 43 Wash. 2d 47, 260 P.2d 331, 336 (1953); Model Code of Evidence rule 215, comment (a) (1942); 8 Wigmore, supra note 2, §§ 2332-33; Reutlinger, Policy, Privacy, and Prerogatives: A Critical Examination of the Proposed Federal Rules of Evidence as They Affect Marital Privilege, 61 CaL. L. REv. 1353, 1358-59 (1973).

Although early attempts to assert a doctor-patient privilege based on the physician's honor as a gentleman were rejected by the courts, the privilege was revived in America in the nineteenth century. See 8 WIGMORE, supra note 2 , $\$ 2380$. From that time on the principal justification advanced for the privilege has been that by freeing patients from the fear of disclosure, it will encourage them to confide in their doctors and thus result in their receiving better medical care. See, e.g., Taylor v. United States, 222 F.2d 398, 401 (D.C. Cir. 1955) (policy viewed as especially strong where the doctor is a psychiatrist); Metropolitan Life Ins. Co. v. Ryan, 237 Mo. App. 464, 172 S.W.2d 269, 272 (1943); МССоRмICK, supra note 3, § 98; 8 Wigmore, supra note 2, § 2380a; Note, Legal Protection of the Confidential Nature of the Physician-Patient Relationship, 52 Colum. L. REv. 383, 385-86 (1952).

In all likelihood the priest-penitent privilege existed at common law prior to the sixteenth century but fell victim to anti-Catholic feeling at the time of the Reformation. 8 WIGMORE, supra note 2, §§ 2394, 2396; Hogan, A Modern Problem on the Privilege of the Confessional, 6 Loy. L. REv. $1,7-13$ (1951). The subsequent decision in the United States that the penitential relationship is socially desirable and should be encouraged is attributable to the value placed on religious tolerance in this country. 8 WIGMORE, supra note 2, \$ 2396; Note, Catholic Sisters, Irregularly Ordained Women and the Clergy-Penitent Privilege, 9 U. CAL. D.L. Rev. 523, 524-25 (1976). As noted above, in many states the privilege has been extended to protect the confidentiality of a wide variety of lay consultations with clergy. See note 4 supra. This expansion probably results from a belief that society will benefit if it encourages laymen to seek spiritual counseling by removing the danger that such communications will be disclosed. See Note, Catholic Sisters, Irregularly Ordained Women and the Clergy-Penitent Privilege, supra, at 538-39.

11. See, e.g., In re Taylor, 412 Pa. 32, 193 A.2d 181, 184-85 (1963); the declaration of legislative intent in the Nebraska Free Flow of Information Act, Neb. REv. STAT. § 20-144 (1974); Note, Reporters and Their Sources: The Constitutional Right to a Confidential Relationship, 80 YALE L.J. 317, 321 (1970).

12. See, e.g., Krattenmaker, Testimonial Privileges in Federal Courts: An Alternative to the Proposed Federal Rules of Evidence, 62 GEo. L.J. 61, 85-94 (1973); Louisell, Confidentiality, Conformity and Confusion: Privileges in Federal Court Today, 31 TuL. L. Rev. 101, 109-11 (1956).

13. The psychotherapeutic relationship has been recognized as one of society's most intimate associations. See Fisher, The Psychotherapeutic Professions and the Law of Privileged Communications, 10 Wayne L. Rev. 609, 616-20 (1964). Agreeing with this view, the California Supreme Court has stated that a patient's interest in maintaining the privacy of revelations made to a therapist forms one basis for the privilege protecting these confidences. In re Lifschutz, 2 Cal. 3d 415, 467 P.2d 557, 85 Cal. Rptr. 829, 839-40 (1970); see generally Louisell and Sinclair, Foreword: Reflections on the 
be that the policy of privacy bears some relation to the doctor-patient ${ }^{14}$ and priest-penitent ${ }^{15}$ privileges and perhaps also to that of attorney-client. ${ }^{16}$

These two policies emphasize different values. They are, however, closely allied and point to the same end. The policy of encouraging desirable confidences applies only to parties to what might be considered confidential relationships. Hence this policy inevitably works hand in hand with that favoring the protection of the privacy of the parties to such relationships. Likewise, an obvious by-product of the policy of privacy is to encourage confidences among the parties to the protected relationships. Indeed, it seems probable that, with the exception of the reporter's privilege, each of these two policies is responsible in various, uncertain and undiscoverable degrees for the privileges discussed above. It follows that when assessing the privilege of another state, the trial court should not waste its time in seeking to determine whether the privilege was based on the policy of encouraging confidences or on that favoring the protection of privacy. Any such attempt would in all probability be fruitless since the policy bases of a privilege will inevitably be obscure. In all probability, both policies were responsible in some degree for the particular privilege. Moreover, as will become evident below, success in isolating a single policy responsible for another state's privilege will not materially aid the court in deciding which state's rule to apply. Finally, and of equal importance, judicial decisions on whether to admit or reject tendered testimony should be made with some dispatch and not deferred until after a tedious, and probably futile, search into a statute's policy background. The privilege that protects communications made to a reporter stands apart from the rest, since it almost certainly is not based on any notions of privacy but rather is designed exclusively to further the interest of the public in being informed by encouraging persons to confide in reporters. ${ }^{17}$ In any event, a court faced with a foreign privilege of the sort discussed above will hardly go wrong in assuming that it is based at least in part on the policy of encouraging confidences.

Law of Privileged Communications-The Psychotherapist-Patient Privilege in Perspective, 59 CaL. L. Rev. 30 (1971). Similarly, the protection of marital privacy has been put forward as one purpose of the privilege which shields from disclosure confidential spousal communications. United States v. Van Drunen, 501 F.2d 1393, 1396 (7th Cir.), cert. denied, 419 U.S. 1091 (1974); Louisell, supra note 12, at 113. Moreover, the United States Supreme Court has defined an area of family privacy that is secure from intrusive regulation by the state. See, e.g., Moore v. City of East Cleveland, $97 \mathrm{~S}$. Ct. 1932 (1977); Griswold v. Connecticut, 381 U.S. 479 (1965).

14. See Black, The Marital and Physician Privileges-A Reprint of a Letter to a Congressman, 1975 Duke L.J. 45, 49-50; Note, Limitations on California Professional Privileges: Waiver Principles and the Policies They Promote, 9 U. CAL. D.L. REv. 477, 484 (1976).

15. See McCormick, supra note $3, \S 77$ at 158 ; Reese, Confidential Communications to the Clergy, 24 Онго Sт. L.J. 55, 60 (1963).

16. See Louisell, The Psychologist in Today's Legal World: Part II, 41 MinN. L. Rev. 731, 743-44 (1957).

17. See note 11 supra. 
It may be argued that on occasion privileges may be recognized for policy reasons that are of special concern to the state of trial. For example, there may be situations where that state would be reluctant to have testimony introduced of a foreign communication for fear that otherwise parties to a similar relationship within the state would be deterred from communicating with one another in the future. ${ }^{18}$ Such a fear, if it were to exist, would be largely unrealistic since it is unlikely that news of the introduction of the testimony at a trial or at a deposition would become sufficiently widespread to have any appreciable effect. It is also conceivable that on some occasions a particular privilege might be based in part on the fact that the state would find it offensive to have introduced in its courts testimony of a communication between parties to a certain relationship, such as that of priest and penitent. ${ }^{19}$ Another possible policy, applicable only to the attorney-client privilege, is that the fair administration of an adversary system of justice requires that an attorney not be compelled to reveal communications made to him by his client. ${ }^{20}$ In criminal cases if the attorney could be compelled to testify about such communications, the client could give the attorney essential information about the case only at the risk of incriminating himself. ${ }^{21}$ Forced disclosure would also burden the client's right to effective counsel. ${ }^{22}$ Finally, it has been suggested that the avoidance of perjury may at times be an additional reason for the recognition of a privilege. ${ }^{23}$ This would be on the notion that a person's loyalty to the other party to the communication may be so strong that he might give unreliable testimony if required to testify. This policy, if it were in fact to exist, would provide the forum with a basis for applying a local rule of privilege to bar testimony of a foreign communication. But it is extremely unlikely that any American rule of privilege would be based, even in part, on such a notion in view of our confidence in the truth-revealing quality of cross-examination and our consequent willingness to allow obviously interested persons to testify. ${ }^{24}$

18. See Weinstein, supra note 1 , at 549 .

19. See, e.g., the statement of Judge Edgerton in Mullen v. United States, 263 F.2d 275, 281 (D.C. Cir. 1958), expressing the view that the decision of the trial court to receive testimony concerning a confidential confession by the defendant to her minister was "shocking to the moral sense of the community . . .."; Note, The Husband-Wife Privileges of Testimonial Non-Disclosure, 56 Nw. U.L. Rev. 208, 218-19 (196I); Note, The Physician-Patient Privilege, 56 Nw. U.L. REv, 263, 267 (1961).

20. See McCormick, supra note $3, \S 87$; Louisell, supra note 16 , at 743 n.46

21. See 8 WIGMORE, supra note $2, \S 2291$ at 552.

22. See Morgan, Foreword to Model Code of Evidence at 27 (1942).

23. See Louisell, supra note 16 , at 750 .

24. In an earlier day when an exaggerated fear of perjury led to the establishment of numerous rules, now discredited, which disqualified categories of witnesses, the same concern may also have played some part in the recognition of certain privileges. See Note, Marital Privileges and the Right to Testify, 34 U. CHI. L. Rev. 196, 198 (1966); Note, The Physician-Patient Privilege, supra note 19 , at $266-67$. 
In this paper we will first discuss the situation where the question of the applicability of a particular privilege is raised at the trial and then turn to the problems which arise when testimony is sought by means of a deposition.

Trial

In our discussion of the situation where the claim of privilege is asserted at the trial, we will consider the interests of three states: (1) that whose law governs the underlying claim, (2) that which has the most significant relationship to the communication about which testimony is sought, ${ }^{25}$ and (3) that where the trial is held. In order to make clear the distinct interests of the three states involved, we will initially direct our attention to a situation where the communication and the parties to the communication bear little or no relation either to the state whose law governs the underlying claim or to the state of trial, and where in addition the latter two states have no relation to one another. We will then have something to say about the more common case where the interests of these states are not as clearly separated. It is thought that discussion can best proceed within the framework of a hypothetical case, to which we now turn.

Let us suppose that the plaintiff, who is domiciled in state $\mathrm{X}$, believes that he has been defamed by an article written by the defendant reporter which appeared in a newspaper whose circulation is confined exclusively to state $\mathrm{Y}$. The defendant relied for his information on statements made to him by an informant in state $\mathrm{Z}$. Suit for defamation is brought in state $\mathrm{X}$ where jurisdiction is obtained over the defendant on the basis of his physical presence. During the course of the trial, the plaintiff's counsel seeks to elicit from the defendant the identity of his informant in an attempt to show that the defendant had been at fault in relying upon the latter and so had forfeited the protection accorded him by recent Supreme Court decisions. ${ }^{26}$ We will assume on the basis of these facts that $Y$ is the state whose law governs the plaintiff's claim in defamation and that $\mathrm{Z}$ is the state which has the most significant relationship to the communication. $X$, of course, is the state of the forum. It is not, however, a naked forum since it is the state of the plaintiff's domicile.

We now turn to an analysis of the interests of the three states involved and of the choice-of-law solutions which these interests suggest. We commence with $Y$, the state whose law governs the claim in defamation. That fact by itself is no reason to apply $\mathrm{Y}$ law on the subject of the reporter's privilege unless the relevant $Y$ rule of defamation is conditioned in some way upon the

25. The process of determining which state will be that of most significant relationship is discussed in the text accompanying note 30 infra.

26. E.g., Gertz v. Robert Welch, Inc., 418 U.S. 323 (1974); New York Times Co. v. Sullivan, 376 U.S. 254 (1964). 
application of the $\mathrm{Y}$ rule of privilege or no privilege. Almost surely there would be no such relationship between the two rules. It follows that the only justification for applying the $\mathrm{Y}$ rule of privilege, or no privilege, would be the notion that all substantive issues should be decided by the law of a single state. Such a notion was widely entertained at one time, but has been generally discarded in light of the influential principle enunciated in Babcock $v$. Jackson that "controlling effect [should be given] to the law of the jurisdiction which . . has the greatest concern with the specific issue raised in the litigation." 27 On the facts stated, Y's law on the subject of privilege should not be applied as it is surely not the state of "greatest concern" with respect to that issue.

On the other hand, $\mathrm{X}$, the state of trial, and $\mathrm{Z}$, the state having the most significant relationship with the communication, do have interests that must be considered. The state of trial has the greatest interest in the manner in which litigation is conducted in its courts and in sparing them unnecessary burdens. For these reasons, that state's rules of evidence should usually be applied. This is not so, however, in the case of rules of privilege. Unlike ordinary rules of evidence, rules of privilege are not designed to aid in the determination of the truth by excluding irrelevant, prejudicial, or untrustworthy material ${ }^{28}$ from the attention of the trier of fact. Rather, rules of privilege are intended to serve the entirely different purposes or policies that have been discussed above. ${ }^{29}$ In addition, the rejection or admission of evidence on the ground of privilege may have a substantial effect upon the ultimate outcome of the case. In short, when the state of trial alone recognizes a privilege, that state should not apply its own rule except in the rare situation where such application is required by one or more of the policies discussed above. ${ }^{29}$ On the other hand, the state of trial does have a distinct interest in having its court ascertain the true facts of a controversy so that it can arrive at the correct result. This interest will frequently lead the trial court to refuse to recognize a foreign rule of privilege.

No court, so far as is known, has given thought to what factors should be considered in determining which is the state of most significant relationship to the communication. In situations where there was no prior relationship be-

27. 12 N.Y.2d 473, 191 N.E.2d 279, 240 N.Y.S.2d 743, 749 (1963); see generally Reese, Dèpeçage: A Common Phenomenon in Choice of Law, 73 Colum. L. Rev. 58 (1973).

28. In the unlikely event that the state of trial did recognize a privilege in order to exclude unreliable evidence, this would provide a reason for a court of that state to apply its rule of privilege. See text accompanying notes 23-24 supra.

29. See text accompanying notes 8-24 supra. In addition a court should not apply its local rule of privilege simply because the statute which enunciates that rule does not specify limits on its application to cases involving out-of-state facts. See Hare v. Family Publications Serv., Inc., 334 F. Supp. 953 (D. Md. 1971). Statutes are usually written with only the local situation in mind and it is exceedingly unwise for a court to assume that a lack of choice-of-law directives in a statute indicates a legislative desire to have the statute govern every relevant case that arises in its courts. 
tween the parties, this state will, usually at least, be that where the communication took place. The problem becomes more complex where there was such a prior relationship. If in such a case the state where the communication took place has no substantial connection to the parties thereto, the state of most significant relationship will presumably be that where the relationship is centered. So, if a communication is made in state $\mathrm{Y}$ between a husband and wife who are domiciled in state $X$ and are in state $Y$ only for the weekend, $X$ should be found to be the state of most significant relationship. As, however, the parties' contacts with the state of communication increase, the choice between that state and the one where the relationship between the parties is centered will become increasingly difficult, ${ }^{30}$ The state which has the most significant relationship with the communication will, almost certainly, have an interest in having its rule of privilege applied. This will be so whether the purpose of the rule in question is to encourage the communication of confidences or to protect the privacy of parties to certain relationships or, as frequently will be the case, to serve both of these ends. For example, in our hypothetical, the purpose of state Z's rule of privilege-to encourage people to communicate with reporters and thus serve the interest of an informed public-would be furthered by application of its rule of privilege.

We turn now to a consideration of various choice-of-law problems. The first situation we will discuss is where the communication is not privileged under the law of the state which has the most significant relationship with the communication but is privileged under the law of the state of trial. Here evidence of the communication should, usually at least, be admitted. ${ }^{31}$ Such admission would surely not be contrary to any interest of the state of most significant relationship. And, assuming that the evidence was relevant, such admission would likewise further the interest of the state of trial in having its court arrive at the truth, or in terms of the hypothetical posed, correctly determine whether the defendant has forfeited his constitutional protection. The fact that the communication would have been privileged if made in the state of trial should not militate against that conclusion. As has been stated above, the purpose underlying a reporter's privilege is to serve the interest of

30. This brief discussion does not exhaust the variety of difficulties which may arise in determining which state is that of most significant relationship. For instance, one recent case presented a situation where numerous communications had been exchanged among several different persons who resided in various states. Hyde Constr. Co. v. Koehring Co., 455 F.2d 337 (5th Cir. 1972). At the present time the problems presented by cases with unusual factual patterns such as Hyde can best be resolved by courts acting in the context of those specific factual settings.

31. In one case a court faced with this situation applied its rule of privilege to exclude evidence on the ground that the issue of privilege is "procedural" and thus automatically governed by the law of the forum. Metropolitan Life Ins. Co. v. McSwain, 149 Miss. 455, 115 So. 555 (1928); see Webster v. Columbian Nat'l Life Ins. Co., 131 App. Div. 837, 116 N.Y.S. 404, aff'd, 196 N.Y. 523, 89 N.E. 1114 (1909). This position, which was also advocated by Restatement of Conflict of LAws $\$ 597$ (1934), is discussed in the text accompanying notes 28-29 supra. 
an informed public by encouraging persons to provide information to reporters. Such a purpose could hardly be served by application of the rule of privilege of the state of trial in situations where, as in our hypothetical, the communication was made in another state between persons who had no relation with the state of trial. Neither the reporter nor his informant could have reasonably acted in reliance upon the application of the rule of privilege of the state of trial. And it seems highly unlikely that the admission of evidence concerning this foreign communication would seriously deter persons from making similar communications to reporters within the trial state itself. There may, of course, be some occasions when the evidence could justifiably be rejected on the ground that to receive testimony concerning a particular confidential communication would seriously offend fundamental notions of the state of trial as to what is appropriate and right. ${ }^{32}$ Instances of this sort, however, would arise only rarely, and it is difficult to believe they would ever involve the reporter's privilege.

We will now examine the more difficult situation where the communication is privileged under the law of the state of most significant relationship but is not privileged under the law of the state of trial. Here the interests of the two states conflict, and the aim should be to reach a result that will accommodate these interests in the best way possible. ${ }^{33}$ First, the forum should make sure that the particular communication was in fact privileged under the law of the state of most significant relationship. For example, if $\mathrm{Z}$, the state of most significant relationship in our hypothetical, were Illinois, the communication to the reporter would not be privileged since the suit was for defamation and thus fell within an exception to the normal reporter's privilege. ${ }^{34}$ In such a situation, the interests of the two states would not conflict and evidence of the communication should clearly be admitted by the forum. ${ }^{35}$ Likewise, there will be situations where, although the communication is privileged under the law of the state of most significant relationship, the effect of the privilege would be substantially qualified in the particular case by some other rule of that state. An example is New York which has a doctor-patient privilege as well as a statute which provides that if an applicant for an insurance policy

32. See text accompanying note 19 supra.

33. For example, if the evidence sought is relatively insignificant or is available from another source, the state of trial should not compel disclosure. See text accompanying note 38 infra.

34. Ill. AnN. Stat. ch. 51, \&111 (Smith-Hurd Supp. 1977) provides:

No court may compel any person to disclose the source of any information obtained by a reporter during the course of his employment except as provided in this Act. The privilege conferred by this Act is not available in any libel or slander action in which a reporter or news medium is a party defendant.

35. See Republic Gear Co. v. Borg-Warner Corp., 381 F.2d 551 (2d Cir. 1967); In re Cepeda, 233 F. Supp. 465 (S.D.N.Y. 1964); People v. Carter, 34 Cal. App. 3d 748, 110 Cal. Rptr. 324 (Ct. App. 1973), cert. denied, 419 U.S. 846 (1974); Woelfling v. Great-West Life Ins. Co., 30 Ohio App. 2d 211,285 N.E.2d 61 (1972). 
has failed to reveal a "medical impairment" and "the insured or any other person having or claiming a right under [the insurance policy] ... shall prevent full disclosure and proof of the nature of such medical impairment, such misrepresentation shall be presumed to have been material." ${ }^{36}$ So in a case where the plaintiff had consulted a doctor in New York and then had brought suit on an insurance contract in another state, there would be little reason for a court of that other state to recognize the New York doctorpatient privilege. This would be so because New York by its enactment of the statute referred to has made clear that it does not wish its privilege to prevent a doctor from testifying at the risk of fraud in insurance cases. Suppose now that a state with a doctor-patient privilege does not have a statute like that of New York but would give effect to a clause in an insurance contract by which the insured waived the privilege in advance ${ }^{37}$ Here also there would be good reason for the trial court to refuse to recognize the privilege even in a situation where the insurance contract made no provision for a waiver. By permitting the privilege to be waived in advance by means of a contract of adhesion the first state has demonstrated that the policy underlying its rule of privilege is one of limited strength. Hence the trial court would be justified in favoring its own interest in the disclosure of all relevant facts that are not privileged under its law. What has been said above should make clear that a court cannot focus its attention exclusively upon the privilege rule of another state in determining the interest of that state in having its rule applied. A rule of law rarely stands in isolation from all others. Frequently the strength and nature of the policy underlying a rule cannot be understood until one has determined the extent, if any, to which the application of the rule is limited and shaped by still other rules.

We now turn to the situation where the state of most significant relationship has not qualified its rule of privilege by some other rule or rules. Here there is an obvious clash between the policy of this state and that of the state of trial, which does not have a similar rule of privilege and hence may be said to attach greater weight to ascertaining the relevant facts of the case than it does to the protection of the confidence in question. The forum should, of course, seek to accommodate these conflicting interests as best as it can. It should, for example, recognize the privilege or, in other words, exclude evidence of the communication in situations where it believes that admission of this evidence would be unlikely to affect the ultimate result of the case or that the essential facts could be conveniently proved in some other way. ${ }^{38}$ So if in

36. N.Y. INS. LAW $\$ 149(4)$ (McKinney 1966).

37. N.J. Stat. Ann. 2A:84A-29 (1976).

New York also permits the privilege to be waived by contract. Lynch v. Mut. Life Ins. Co. of N.Y., 55 Misc. 2d 179, 284 N.Y.S.2d 768 (Sup. Ct. 1967).

38. This alternative was apparently available to the court in Doll v. Equitable Life Assur. Soc'y of the United States, 138 F. 705 (3d Cir. 1905). In Doll, a resident of New Jersey brought suit in 
our hypothetical the communication to the reporter was privileged under the law of $\mathrm{Z}$, the state of most significant relationship, but not under the law of $\mathrm{X}$, the state of the forum, the $X$ court should exclude evidence of the communication if it believes that admission of the evidence would not be necessary to the plaintiff's case or that satisfactory evidence of the identity of the reporter's informant and of the facts communicated to the reporter could be obtained from some other source. In addition, along with its policy of seeking the truth, the state of trial will undoubtedly have another policy favoring the protection of justified expectations. Hence the state of trial may be reluctant to refuse recognition of the privilege if it believes that the communication was made in reliance upon the existence of the privilege or, what is more likely, since persons would rarely be aware of the rule of law involved, in reliance upon the fact that communications of the sort in question are treated with utmost confidence in the state where the communication took place. In situations where the state of trial has few contacts with the case, a reluctance to infringe a foreign privilege might serve as one of a number of factors leading to the conclusion that the suit should be dismissed on the ground of forum non conveniens. This would be particularly true if there were reason to believe that suit had been brought in the state of trial in order to escape the particular rule of privilege. But where the trial court feels compelled to reach a decision on the merits, it will perforce have to consider its own interest in arriving at the true facts of the case. The trial court can hardly be expected to subordinate this interest in favor of a foreign privilege in situations where evidence of the communication would be essential to the case.

In these situations where evidence of the communication is crucial, it could even be argued that the trial court should receive the evidence in disregard of a foreign privilege that is identical to one found in its own law. The argument would be that by admitting the evidence the court would serve its interest in arriving at the truth and would not violate the policy of its own rule of privilege which would be concerned exclusively, or at least primarily, with communications that took place within that state. This argument should be rejected. By creating a privilege the state of trial has made clear that it places a higher value on preserving the confidentiality of local communica-

that state to recover the proceeds of a life insurance policy of which she was the beneficiary. One of the insurance company's defenses was that the assured had falsely stated on his application for the policy that there was no history of tuberculosis in his family when in fact his sister, a resident of New York, had died of that disease. At the time, New York recognized a doctor-patient privilege while New Jersey did not. The insurance company was permitted to prove the existence of the sister's illness in part through the testimony of a New York doctor who had treated her in that state. The company also produced other witnesses, not physicians, who were familiar with the sister's illness. It may be that by limiting the insurance company to the testimony of the lay witnesses and barring the testimony of the doctor, the court could have respected the interest of New Jersey in ascertaining the truth while not sacrificing the interest of New York in permitting its residents to confide in their doctors without fear of disclosure. 
tions than it does on arriving at the truth. Failure to recognize a foreign privilege based on the same values as those prevailing in the forum would ignore the value of seeking to accommodate conflicting interests and thus be antithetical to the needs of a multistate system.

Up to this point, we have been discussing a hypothetical situation where the contacts relating to the communication are grouped in one state, those concerned with the underlying claim are grouped in a second state, and no contact bearing upon either of these two matters is to be found in the state of trial. Such a situation is unlikely to occur but merits discussion nevertheless in order to make clear the diverse interests involved. In truth the vast majority of cases will fall into one of two categories: (1) contacts of significance to the privilege or to the underlying claim will be spread among the three states or (2) what is more likely, only two states will be involved with (a) the state of trial being in addition either that whose law governs the underlying claim or that which has the most significant relationship to the communication or (b) the state whose law governs the underlying claim being also that of most significant relationship to the communication. These two categories can be discussed together.

Almost invariably, contacts of some significance will be found in the state of trial for otherwise dismissal of the suit on forum non conveniens grounds would usually be appropriate. Even in our hypothetical the plaintiff's domicile was placed in $\mathrm{X}$, the state of trial. As a result, $\mathrm{X}$ already has an interest in the outcome of the suit. ${ }^{39}$ The fact of this interest would undoubtedly make the $X$ court even more reluctant than it otherwise would be to recognize a foreign privilege unknown to its own law at the risk of making it impossible for the plaintiff to prove facts essential to his case. The situation would be quite different if the reporter's informant, rather than the plaintiff, had been domiciled in X. Here, if the state of trial had the reporter's privilege and $\mathrm{Z}$, the state of most significant relationship, did not, it could persuasively be argued that the former would have a considerable interest in applying its rule of privilege. This would be on the ground that it is the policy of the state of trial to encourage its residents to speak freely to reporters and these residents could be expected to act the same way in other states as they are encouraged to act in the state of trial. Hence it would not be surprising to find the trial court applying its rule of privilege in this situation even though there was no such privilege in $\mathrm{Z}$, the state of most significant relationship.

In general, it can be said that the more contacts the state of trial has with the case the greater will be its reluctance to recognize a foreign privilege which it does not have itself. ${ }^{40}$ On the other hand where the state of trial has

39. But not enough, it is thought, to warrant application of its law of defamation to the underlying claim.

40. See Metropolitan Life Ins. Co. v. Brubaker, 78 Kan. 146, 96 P. 62 (1908). There would 
the privilege and the state of most significant relationship to the communication does not, the fact that relevant contacts are grouped in the state of trial should make the trial court more inclined to apply its own rule of privilege and refuse to admit evidence of the communication. In situations where the state of trial is also that of most significant relationship, a relevant rule of privilege of that state will, of course, be applied. ${ }^{41}$

Usually the state whose law governs the underlying claim will have some relationship to the communication. This is so even on the facts of our hypothetical where it will be recalled that information obtained by a reporter in state $\mathrm{Z}$ forms the basis of an account published exclusively in state $\mathrm{Y}$, which therefore is assumed to be the state whose law governs the plaintiff's claim in defamation. If $\mathrm{Y}$ has the reporter's privilege, it could be argued that $\mathrm{Y}$ would have an interest in having its rule of privilege applied even though the communication in question took place in state $Z$. This would be on the theory that the ultimate purpose of the $\mathrm{Y}$ rule of privilege is to produce an informed public in Y. The difficulty with this argument is that the reporter's privilege is normally thought to be designed to encourage those who communicate with reporters. In this case the communication occurred in state $\mathrm{Z}$, and it is highly unlikely that the reporter's informant relied upon the $Y$ privilege. Nevertheless, the argument might be made that another purpose of the $\mathrm{Y}$ privilege is to encourage $\mathrm{Y}$ reporters to seek confidential information wherever this might be available with the expectation that such communications would be held to be privileged in any suits brought in Y. ${ }^{42}$ We doubt that such an argument would persuade the court of a second state to apply the $Y$ privilege. On the other hand, if $\mathrm{Y}$ were the state of trial, a $\mathrm{Y}$ court might conceivably succumb to it.

II

\section{Depositions}

We now turn to the problems that have arisen most frequently in the reported cases, namely where the evidence claimed to be privileged is sought by deposition outside the state of trial. ${ }^{43}$ To date, the claim of privilege has usu-

\footnotetext{
be an exception, of course, where the state of trial was connected to the case because it was the residence of a party who had relied on the privilege of the state of most significant relationship.

41. See Brotherhood of Ry. Trainmen v. Long, 186 Ark. 320, 53 S.W.2d 433 (1932).

42. See Neb. Rev. Stat. $\S 20-144(2)$ (1974) which declares that it is the policy of that state to encourage reporters to "gather... news or other information vigorously so that the public may be fully informed. ..."

43. We use "deposition" in its broad sense to include the situation where information is sought by means of interrogatories. The issue of privilege can also arise in the context of other discovery proceedings such as an effort to obtain evidence through the use of a subpoena duces tecum.
} 
ally been raised in either the state of trial or in the state where the deposition is to be conducted. These two situations will be discussed in the order stated.

\section{A. The Claim of Privilege is Raised in the State of Trial}

A claim of privilege may be raised in various ways in the state of trial. It may be raised when a party asks a court of that state for authorization to conduct a deposition in another state ${ }^{44}$ or, if the deposition is sought on notice, when a court of the trial state is requested either to forbid the taking of the entire deposition or to prohibit examination along certain lines of inquiry. ${ }^{45}$ Less frequently, if the privilege is claimed at the deposition, a court of the state of trial may be requested to order a witness to supply the information sought, ${ }^{46}$ or to suppress inquiry into matters claimed to be privileged. ${ }^{47}$

Three possible situations should be considered. The court of the state of trial may be convinced that it would recognize the privilege and refuse at the trial to receive the evidence obtained in the deposition. Instead, the court may be convinced that it would not recognize the privilege and would receive the evidence. Finally, the court may be uncertain as to what its decision at the trial would be.

When the court is convinced that it would recognize the privilege and refuse to receive the evidence, it should not order the deposition to proceed and thus compel the parties to engage in a useless act. ${ }^{48}$ Similarly, when the deposition is to be taken on notice, it would be appropriate for the court, upon request, to forbid the taking of evidence which it would ultimately refuse to receive.

The situation is different where the court is convinced that it would not recognize the privilege and would admit the evidence at the trial. In this event, it is in the interest of the state of trial that the deposition take place in order to make available evidence that will assist its courts in arriving at the truth. Clearly, the court should order that the deposition proceed in situations

44. See, e.g., Lorde v. Guardian Life Ins. Co. of America, 252 App. Div. 646, 300 N.Y.S. 721 (1937); Levy v. Mutual Life Ins. Co. of N.Y., 56 N.Y.S.2d 32 (Sup. Ct. 1945); N.Y. Civ. Prac. LAW $\$ 3108(1970)$.

45. See, e.g., R. \& J. Dick Co. v. Bass, 295 F. Supp. 758 (N.D. Ga. 1968); Fed. R. Civ. P. 26(c).

46. Ser, e.g., Cervantes v. Time, Inc., 464 F.2d 986 (8th Cir. 1972), cert. denied, 409 U.S. 1125 (1973); Hare v. Family Publications Serv., Inc., 334 F. Supp. 953 (D. Md. 1971); Fed. R. Crv. P. $37(\mathrm{a})$.

47. See, e.g., FED. R. CIV. P. 30(d).

48. In several cases, a court of the trial state has refused to authorize a foreign deposition as a result of a decision. erroneous in our opinion, that the evidence sought should be rejected at trial simply because it would be privileged under a rule of the trial state. Lorde $v$. Guardian Life Ins. Co. of America, 252 App. Div. 646, 300 N.Y.S. 721 (1937); In re Meyer's Estate, 206 Misc. 368, 132 N.Y.S.2d 825 (Sur. Ct. 1954); Wexler v. Metropolitan Life Ins. Co., 38 N.Y.S.2d 889 (N.Y. City Ct. 1942); see Hare v. Family Publications Serv., Inc., 334 F. Supp. 953 (D. Md. 1971). The reasons why a court of the state of trial should not apply its rule of privilege in cases such as these are discussed in the text accompanying notes 28-29 and 31-32 supra. 
where there is no reason to suppose that the privilege would be recognized in the deposition state. ${ }^{49}$ And, usually at least, the court should do the same even when it has reason to believe that the evidence would be considered privileged under a rule of the deposition state. Here again it is in the interest of the state of trial that the deposition proceed, and rarely, if ever, will the court know with certainty that the deposition state would forbid the taking of the evidence. Apart from the difficulty that might be involved in interpreting correctly the relevant rule of privilege of the deposition state, there would be the further question whether the deposition state would apply this rule to a communication that took place in another state. We have seen that the forum should not usually apply its rule of privilege to bar evidence of a foreign communication. ${ }^{50}$ And, as will be discussed below, the deposition state should be even more reluctant, at least in situations where it is not also the state of most significant relationship to the communication, to bar the taking of testimony for use in another state. ${ }^{51}$ For all of these reasons, it is thought that, in general, a court of the state of trial should order that the deposition proceed. ${ }^{52}$

There will be occasions when at the time the deposition issue arises, the court of the state of trial will be uncertain whether it would ultimately receive the evidence. This may be so, for example, where the court lacks facts necessary to determine which is the state with the most significant relationship to the communication or where it is not yet clear whether the evidence being sought by the deposition is essential to the case and could not be established in some other way. Despite such uncertainty, it would be in the best interests of the state of trial to have the evidence available in the event that it should be held admissible. Thus the court should, as a general rule, order that the deposition proceed.

\footnotetext{
49. See Levy v. Mutual Life Ins. Co. of N.Y., 56 N.Y.S.2d 32 (Sup. Ct. 1945).

50. See text accompanying notes 28-29, 31-32 supra.

51. See text accompanying notes 56-58 infra.

52. It may happen that the state where the deposition is to be held will, on the request of a party or a witness, decide to apply its rule of privilege and bar the inquiry. However, if the evidence being sought is important to the fair resolution of the case, a court of the state of trial may wish to continue its efforts to obtain the information in order to vindicate its interest in ascertaining the truth and to avoid unfairness to a litigant who is denied access to facts that are essential to his case. Although the court undoubtedly will refrain from taking the extreme step of holding in contempt a party who fails to produce the evidence in these circumstances, a wide range of sanctions other than contempt is available. The court may order the party to waive the privilege. See Abety v. Abety, 10 N.J. Super. 287, 77 A.2d 291 (Ch. Div. 1950). Or the party may be required to procure the evidence on pain of being prohibited from introducing proof on a given point, or even of having the entire suit dismissed. The propriety of employing these sanctions will depend in part on the importance of the evidence being sought, on whether the person claiming the privilege is a party or stands in relation to a party, and on the party's good faith efforts to obtain the evidence. See Societe Internationale v. McGranery, 111 F. Supp. 435 (D.D.C. 1953), aff'd sub nom. Societe Internationale v. Brownell, 225 F.2d 532 (D.C. Cir. 1955), modified sub nom. Societe Internationale v. Rogers, 357 U.S. 197 (1958).
} 
B. The Claim of Privilege is Raised in the Deposition State

A claim of privilege may be raised in the deposition state whenever a court of that state is requested to determine whether, and under what conditions, a deposition may proceed.$^{53}$ There are two possible situations: when the matter is not privileged under the law of the deposition state and when the opposite is true.

When its law does not provide for the privilege, the deposition state should, as a general rule, require the deposition to proceed. By doing so, it will serve the cause of interstate (or international) cooperation by assisting the courts of the state of trial in arriving at the truth. It will also be serving its own convenience since, by applying its own law which does not recognize the privilege, it avoids the difficulties that are inevitably involved in the application of the law of another state. There may, of course, be a number of complicating factors. For example, it may be contended that the trial court would ultimately reject the evidence by application of its own rule of privilege. If this is demonstrably so, the deposition should not be permitted to proceed since there would be no purpose in requiring the parties to perform a useless act. But it will be the rare case when such certainty will exist; for, as stated above, evidence should frequently be accepted in the state of trial even though it is privileged under that state's law. ${ }^{54}$ Thus, under these circumstances, the deposition should generally be ordered to proceed and the ultimate admissibility of the evidence left for determination by the trial court. ${ }^{55}$

The problem is more difficult where the deposition court is convinced that the evidence would be privileged under the law of the state with the most significant relationship to the communication. It is in the interests of this state that the deposition not take place provided, as would almost certainly be the case, that one purpose of its rule of privilege is either to encourage the communication of confidences or to protect privacy. If in addition to being privileged under the law of the state of most significant relationship, it is also clear that the evidence would be privileged under the law of the state of trial, a proper accommodation of the interests of these two states would seem to require that the deposition not be permitted to proceed. Where, on the other hand, the evidence would be privileged in the state of most significant rela-

53. Before the deposition is taken, a court of the deposition state can be asked to bar the proceeding or to limit its scope. See, e.g., FED. R. CIV. P. 26(c). If the privilege is claimed at the deposition, an order may be sought in a court of the deposition state to compel the witness to answer. See, e.g., Metropolitan Life Ins. Co. v. Kaufman, 104 Colo. 13, 87 P.2d 758 (1939); In re Franklin Washington Trust Co., 1 Misc. 2d 697, 148 N.Y.S.2d 731 (Sup. Ct. 1956); Fed. R. Civ. P. 37(a). Alternatively, a motion may be brought to limit or terminate the examination. See, e.g., FED. R. CIv. P. 30(d).

54. See text accompanying notes 31-32 supra.

55. A case that reaches this result but for different reasons is Hill v. Huddleston, $263 \mathrm{~F}$. Supp. 108 (D. Md. 1967). 
tionship but not in the state of trial, the deposition state is in the difficult position of having to determine which of the conflicting interests it will further. The choice is made more difficult by the fact that the deposition state occupies a neutral position and does not have as substantial an interest as the state of trial in arriving at the correct result in the litigation. One possibility would be for the deposition court to make its decision depend upon the answer to such questions as whether the information sought was essential to the case or could be obtained in other ways or whether the parties to the communication acted in reliance on the law of the state of most significant relationship. However, the deposition court would generally find it burdensome or perhaps even impossible to answer these questions. Usually the most practical and expeditious course would be to permit the deposition to proceed and leave the question of the admissibility of the evidence for decision by the trial court.

We now turn to the problems which arise when the evidence would be privileged under the law of the deposition state. Here two situations must be distinguished: (1) where the deposition state has no relationship with the communication and (2) where such a relationship exists. Except on rare occasions, the deposition state should not bar the taking of the evidence in the first situation simply on the basis of its own rule of privilege. As stated in an earlier portion of this paper, the basic purpose of a rule of privilege will usually be the encouragement of what are thought to be desirable confidences. ${ }^{56}$ Such a purpose would hardly be served by application of the deposition state's rule of privilege when it has no relationship with the communication. Moreover, in these circumstances, the parties to the communication could not reasonably have acted in reliance on the privilege. Finally, it is unlikely in the extreme that allowing the evidence to be taken would deter persons in the future from making similar communications in the deposition state, for the reason, among others, that judicial decisions on such arcane subjects as depositions will virtually never come to the attention of the general public. There may perhaps be occasions where the deposition state would be justified in refusing to permit the evidence to be taken on the ground that it values the privacy of a particular relationship so highly that it would find it offensive to permit inquiry even into a relationship with which it has no connection. Such occasions, if they should ever arise, will do so rarely. ${ }^{57}$

56. See text accompanying notes 8-11 supra.

57. Another unusual situation that might lead a court of the deposition state to refrain from attempting to compel testimony would arise if both the states of deposition and trial recognized the privilege, and in addition the deposition court felt with some degree of certainty that the trial court would apply its rule and refuse to receive the evidence. Since in those circumstances compelling disclosure could well be a futile gesture, the deposition court might not wish to take the harsh step of punishing for contempt an unwilling witness who is, after all, adhering to a course of conduct that is sanctioned under the law of the deposition state. 
The situation is different where the evidence is privileged both under the law of the deposition state and under that of the state with the most significant relationship to the communication. Here it seems appropriate that the deposition state should bar the taking of the evidence in deference to the common policy that it shares with the state of most significant relationship. The deposition state should obviously apply its rule of privilege to forbid the taking of the testimony in situations where it is also the state of most significant relationship. ${ }^{58}$ In such a case, a refusal by this state to recognize the privilege would serve to deter the very confidences its rule of privilege is designed to encourage and also quite possibly to disappoint the reasonable reliance of the parties upon the application of this state's rule. The deposition state may also be justified in applying its rule of privilege to forbid the taking of testimony in situations where, although it is not the state of most significant relationship, it does nevertheless have a substantial interest in the parties to the communication. To use an example similar to the one adverted to above, suppose that the deposition state has the reporter's privilege and that one of its residents gives confidential information to a reporter in an adjoining state which does not have the privilege. Here the deposition state might well bar the examination of the reporter on the ground that to do so would serve the purpose of its rule of privilege. This would be on the basis that the rule is designed to encourage the giving of information to reporters and that, in this respect at least, residents of the state could be expected to act in the same way that they do at home. Speaking generally, the greater the interest that the deposition state has in the parties to the communication the greater is the likelihood that its court will apply its rule of privilege to bar the taking of the evidence.

\section{Conclusion}

The encouragement of confidences is believed to be the basic policy underlying the testimonial privileges that have been discussed above. Some rules of privilege are also supported by another policy, the protection of the privacy of certain relationships. These two policies, where they co-exist, will be closely intertwined and, by and large, will point to the same end. Except where a foreign rule of privilege has a clear legislative history, the forum should not attempt the arduous, probably impossible, and generally pointless task of identifying the basic policy on which the rule is based. At the least, the

58. Although it is at times difficult to be certain from the court's discussion of the facts that a particular case fits this category, it appears that several reported decisions have reached the proposed result though for a variety of reasons. See Palmer v. Fisher, 228 F.2d 603 (7th Cir. 1955), cert. denied, 351 U.S. 965 (1956); Ex parte Sparrow, 14 F.R.D. 351 (N.D. Ala. 1953); In re Walsh, 40 Misc. 2d 413, 243 N.Y.S.2d 325 (Sup. Ct. 1963); In re Queen, 233 N.Y.S.2d 798 (Sup. Ct. 1962). 
forum can safely assume that the encouragement of confidences is an important policy served by the rule.

One of the situations considered above is where the state of trial has the privilege and the state with the most significant relationship to the communication does not. Here the evidence should be admitted except in the rare case where to do so would seriously offend the trial state's notions of what is appropriate and right. Where, however, the situation is reversed and it is the state of most significant relationship that has the privilege, the task of the trial court should be to arrive at the best accommodation that it can between the conflicting interests of the two states. Even in this situation, the evidence should frequently be admitted.

When a court of the state of trial is requested to order that a deposition take place in another state, the court should not usually be deterred from doing so by the fact that the evidence would be privileged under the other state's law. On the other hand, the court should not issue such an order if it is convinced that the evidence obtained would ultimately be rejected at the trial.

A court in the deposition state should not usually bar the inquiry simply because the evidence sought would be privileged under a rule of the state of trial. Rather, the deposition should be permitted to proceed and the question of the admissibility of the evidence left for decision in the latter state. On the other hand, the deposition court should bar the inquiry if the evidence would be privileged both under the law of the state of trial and under that of the state with the most significant relationship to the communication. Likewise, the court should bar the inquiry where the evidence is privileged both under its own law and under that of the state of most significant relationship. A court in the deposition state should not forbid the inquiry solely because the evidence would be privileged under its local rule unless either the deposition state has a substantial relationship to the communication in question or in the unlikely event that admission of the evidence would seriously affront the deposition state's concepts of what is appropriate and right. 